\title{
O bibliotecário em pauta na prática de contar histórias: uma atividade educativa incentivada nas bibliotecas escolares da Grande Vitória, Espírito Santo, Brasil
}

The librarian on the agenda in the practice of storytelling: an educational activity encouraged in school libraries in Grande Vitória, Espírito Santo State, Brazil

El bibliotecario en pauta en la práctica de contar historias: una actividad educativa impulsada en las bibliotecas escolares de Grande Vitória, Espírito Santo, Brasil

\begin{abstract}
Marcelo Calderari Miguel Especialista Educação Científica pela Universidade Federal de Minas Gerais - UFMG, Brasil. Pesquisador - Programa Institucional de Iniciação Científica e Tecnológica da Universidade Federal do Espírito Santo - UFES, Brasil. https://orcid.org/0000-0002-7876-9392 E-mail: marcelo.miguel@edu.ufes.br

Sandra Maria Souza de Carvalho Servidora Municipal da Prefeitura de Domingos Martins, ES, Brasil. MBA em Biblioteconomia pela Faculdade Alfa América - ALFAMÉRICA, SP, Brasil. http://orcid.org/0000-0002-7418-1874

E-mail: $\underline{\text { sandramsc@ hotmail.com }}$
\end{abstract}

\section{Resumo}

O ato de contar histórias acompanha a humanidade desde os primórdios e, essa trajetória impõe e vem estruturando novos âmbitos de atuação. Assim, o objetivo do estudo é analisar e compreender o ato de contar histórias na trajetória profissional de alguns bibliotecários escolares que atuam no Ensino Fundamental na região metropolitana de Vitória, Espírito Santo, Brasil (RMGV-ES). A articulação metodológica baseia-se no método da História de Vida e, retoma as narrativas profissionais e as examina numa abordagem sócio-interacionista. O resultado situa que a contação de histórias é uma manifestação que entrelaça a imaginação e a criação; e tal arte se apoiando muitas vezes em uma subjetividade transformadora que faz com que se mantenha viva e disseminada a memória comunicativa e cultural. Em síntese, na via da ação cultural, o ato de contar histórias reconstruí e ressignifica a conjuntura das práticas leitoras e, em geral, os entrevistados assinalam que o curso de graduação não os prepara para a realização dessas atividades. Nesse painel, sugerem os profissionais que o ato de contar histórias deve ser incluído no currículo dos cursos de biblioteconomia. Assim, a biblioteca escolar tem a incumbência de ser um orbe de conhecimento, flexibilidade cultural, exercício da cidadania e locus creationis - para múltiplas trocas e intervenções literárias. A conclusão situa que a ação de contar histórias traz significado e valor para o processo ensino-aprendizagem na educação, principalmente para alunos do ensino fundamental. Frisa-se que a biblioteca escolar e o bibliotecário, com a contação de histórias, auxiliam o desenvolvimento educacional e social do discente, estimulando o mundo da imaginação e o despertar de novos leitores.

Palavras-chave: Mediação de Leitura e Informação. Contador de Histórias. Bibliotecário escolar. História de Vida. Formação do Leitor.

Bibl. Esc. em R., Ribeirão Preto, v. 7, n. 2, p. 17-41, 2021. 
O bibliotecário em pauta na prática de contar histórias: uma atividade educativa incentivada nas bibliotecas escolares da Grande Vitória, Espírito Santo, Brasil

\begin{abstract}
The act of telling stories has accompanied humanity since the beginning and this trajectory imposes and has been structuring new actuation areas. Thus, the objective of the study is to analyze and understand the storytelling act in some school librarians who work in elementary school professional trajectory in Vitória, Espírito Santo State, Brazil (RMGV-ES) metropolitan area. The methodological articulation is based on the Life History method and, takes up the professional narratives and examines them in a socio-interactionist approach. The result is that storytelling is a manifestation that intertwines imagination and creation, often relying on a transformative subjectivity, keeps communicative and cultural memory alive and disseminated. In short, in the path of cultural action, the act of telling stories rebuilds and reframes the conjecture of reading practices and, in general, interviewees indicate that the graduation course does not prepare them for carrying out these activities. In this panel, professionals suggest that the act of storytelling should be included in the curriculum of library science courses. Thus, the school library has the task of being an orb of knowledge, cultural flexibility, citizenship exercise and locus creationis - for multiple exchanges and literary interventions. The conclusion states that the action of storytelling brings meaning and value to the teaching-learning process in education, especially for elementary school students. It is emphasized that the school library and the librarian, with storytelling, help the student educational and social development, stimulating the imagination world and the awakening of new readers.
\end{abstract}

Keywords: Mediation of Reading and Information. Story teller. School librarian. Life's history. Reader training.

\title{
Resumen
}

El acto de contar historias ha acompañado a la humanidad desde sus inicios y esta trayectoria impone y ha ido estructurando nuevas áreas de acción. Así, el objetivo del estudio es analizar y comprender el acto de contar historias en la trayectoria profesional de algunos bibliotecarios escolares que trabajan en la escuela primaria y en la región metropolitana de Vitória, Espírito Santo, Brasil (RMGV-ES). La articulación metodológica se basa en el método Life History y retoma las narrativas profesionales y las examina con un enfoque sociointeraccionista. El resultado es que la narración es una manifestación que entrelaza la imaginación y la creación, a menudo apoyándose en una subjetividad transformadora, mantiene viva y diseminada la memoria comunicativa y cultural. En resumen, en el camino de la acción cultural, el acto de contar historias reconstruye y refresca la coyuntura de las prácticas lectoras y, en general, los entrevistados señalan que la carrera de grado no los prepara para estas actividades. En este panel, los profesionales sugieren que el acto de contar historias debe incluirse en el plan de estudios de los cursos de biblioteca. Así, la biblioteca escolar tiene la tarea de ser un orbe de conocimiento, flexibilidad cultural, ejercicio de ciudadanía y locus creationis - para múltiples intercambios e intervenciones literarias. La conclusión afirma que la acción de contar historias aporta significado y valor al proceso de enseñanzaaprendizaje en la educación, especialmente para los estudiantes de primaria. Se destaca que la biblioteca escolar y la bibliotecaria, con el cuentacuentos, ayudan al desarrollo educativo y social del alumno, estimulando el mundo de la imaginación y el despertar de nuevos lectores.

Palabras clave: Mediación de la lectura y la información. Cuentacuentos. Bibliotecario escolar. Historia de vida. Formación de lectores. 


\section{Considerações iniciais: tecendo novas tramas sociais}

A arte figurativa de narrar histórias e declamar versos (fluência oral arrola o incremento de vocabulário) remonta séculos de existência humana e constitui uma prática cultural que antecede o desenvolvimento da escrita. Desde tempos remotos e ainda hoje, a necessidade de exprimir os sentidos da vida, buscar explicações para inquietações e transmitir valores, tem sido a força que impulsiona o ato de contar, ouvir e recontar histórias.

Assim, o ato de contar histórias tem a incumbência de difundir conhecimentos e valores. As narrativas orais são uma prática muito antiga e de grande relevância na coesão do grupo social. Afinal, o Homo habilis (dotado de rudimentos de linguagem e, última espécie antes da linhagem sapiens arcaica) teria surgido há ao menos 2,5 milhões de anos (PIVETTA, 2019). As histórias se tornam atividade fundamental na transmissão de valores e conhecimentos, uma vez que sua atuação é coadjuvante na formação e no desenvolvimento do processo ensinoaprendizagem.

A contação de história além de pertencer ao campo da educação e à área das ciências humanas, é uma atividade comunicativa. Por meio dela, os homens repassam um conjunto de tradições, crenças e costumes de determinado grupo social. Valores capazes de estimular a formação do cidadão. Contar histórias situa um átimo de fantasia (momento mágico) e expressa um processo participativo que envolve diversos setores e organizações da sociedade civil.

Uma ação cultural - contação de história - incentiva não somente a imaginação, mas também o gosto da leitura, a ampliação do vocabulário, conjunto de elementos referenciais que proporcionarão o desenvolvimento do consciente e subconsciente infantil (MATEUS et al., 2013). Aliás, o contar histórias não está ligado somente a lastro da infância e, de certa forma, envolve relações plurais entre o espaço íntimo do sujeito (mundo interno) com o mundo social (mundo externo), resultando na formação da personalidade do indivíduo, na perpetuação de história, memórias e imagens.

Destarte, a contação de história, quando "somada à intervenção do profissional", e esta se utiliza da dinâmica e da criatividade para realizar tal tarefa, faz com que haja participação e compreensão dos interagentes para "atuar incentivando seu imaginário" (COSTA; RIBEIRO, 2017, p. 12). Assim, a oralidade instiga a imaginação, a vivacidade e incentiva o gosto pela leitura, contribui na formação da personalidade envolvendo aspectos físico-motor, intelectual, afetivo-emocional e social. 
O bibliotecário em pauta na prática de contar histórias: uma atividade educativa incentivada nas bibliotecas escolares da Grande Vitória, Espírito Santo, Brasil

Por isso, contar histórias (para crianças, jovens, adultos e idosos) significa saber criar um ambiente de encantamento, suspense, surpresa e emoção, no qual o enredo e os personagens ganham vida, transformando o ânimo do narrador e do ouvinte. Isso promove à reunião de pessoas, em torno de um (a) contador (a), que, por sua vez, gera o momento de encantamento e perplexidade. São basais para o curso do processo estético, os recursos que o contador de história emprega para envolver o seu público, isto é: a voz, o olhar, o seu estado de espírito, o domínio sobre a história a ser narrada.

Ao narrar histórias o bibliotecário estabelece com o aluno um clima de cumplicidade que os remete à época dos antigos contadores que, ao redor do fogo, relatavam a uma plateia atenta às histórias, tradição e costumes do seu povo - nas situações de conflitos que aparecem no seu cotidiano, em seu meio social. Desta forma, o presente diagnóstico situacional busca compreender a articulação da construção histórica dos bibliotecários e das suas conexões com o valor simbólico auferidos no método História de vida. Esse método é interessante para o desenvolvimento de pesquisas na área da Ciência da Informação (CI), garantindo uma aproximação entre os sujeitos da pesquisa e o pesquisador, além disso, o processo de recorrer as histórias de vida se dá no tempo de (re)encontros com o entrevistador e o respondente.

No âmbito da CI, reconhece-se que a necessidade de atingir novos patamares na pesquisa acerca da literacia familiar e a contação de história para crianças que estão no primeiro ciclo do ensino é um grande desafio para as políticas sociais, em diferentes linhas de pensamento e com diferentes abordagens, em especial, para seus investigadores. Já o conceito 'biblioteca escolar' constitui um objeto de ampla investigação na CI. Nesse campo, busca-se refletir sobre a definição na estrutura educacional moderna. Garcez (2014) e Severino e Bedin (2016), por exemplo, garantem que a biblioteca escolar serve para articular e apoiar o desenvolvimento de atividades curriculares e atingir as metas educacionais - ao se motivar e formar o hábito do uso, a biblioteca escolar precisa ter profissionais atuantes para se multiplicar a participação ativa e se o potencializar o capital humano e institucional.

Não obstante, embora haja a Lei no 12.244 de 24 de maio de 2010 - que dispõe sobre a universalização das bibliotecas nas instituições de ensino do País, nota-se, que, essa é uma realidade que está ainda está longe de vigorar (FREITAS, 2018) conforme sanção e vênia da redação final. Assim, a escola é 'uma biblioteca rodeada por salas de aula' (FREITAS, 2018) e isso evidencia, uma vez mais, que formas de aprendizado, leitura e a pesquisa ocorrem por meio da biblioteca. 


\section{A prática e arte milenar de contar histórias}

As histórias despertam no ouvinte a criatividade, a emoção e o fascínio da escrita e da leitura. Afinal, contar histórias é revelar segredos, é seduzir o ouvinte e convidá-lo a se entusiasmar pelas narrações e deciframentos (implica uma interpretação do texto e do mundo escondido atrás dele) - cabal exercício de cidadania. De tal modo, essa revisão de literatura pauta três breves investidas: o histórico (2.1); o âmago do profissional (2.2) - que durante a pandemia da Covid-19 (doença infecciosa causada pelo novo coronavírus SARS-CoV-2). Já o substrato (2.3) expõe a Biblioteca escolar, a qual é mister do direcionar a reflexão de alguns aspectos (heterogêneos impactos) nessa conjectura.

\subsection{Uma visão historiográfica do contar histórias}

Contar história é uma das tradições mais remotas que se tem registro da humanidade. Nesse sentido os tópicos a seguir irão destacar diretrizes dessa arte. Para Giordano (2013), tratase de uma atividade de berço cultural e de registro histórico provado pelos diversos contextos socioculturais contemporâneos. Assim, a prática da contação tornou-se um dos principais meios de preservação dos princípios de uma comunidade.

$\mathrm{Na}$ cultura primitiva, as histórias situam uma maneira mais significativa que a humanidade encontrou para "expressar experiências que, nas narrativas realistas, não acontecem" (MATEUS et al., 2013, p. 55). Além disso, com o passar dos anos, as histórias/estórias tornam-se também um cenário mais significativo que os povos encontraram para as práticas de memórias orais distintas, as quais apresentam grandes semelhanças em suas origens, características e conceitos.

Fleck, Cunha e Navarra (2018) e Sousa, Sá e Bufrem (2020) acrescentam que a contação de histórias pode ser analisada pelo "seu poder" para estimular o aprendizado e transmitir informações em prol da coletividade, e, de tal modo, o universo e império do cativar com histórias é bastante vasto, adequando-se a espaços e a diversos fins.

Barreto e Sousa (2017, p. 203) salientam que "apesar do costume de narrar histórias ser uma tradição muito antiga, a expressão 'Contação de Histórias' só foi empregada a partir das últimas décadas do século XX”. Por conseguinte, o Quadro 1 aborda as circunstância espaço- 
O bibliotecário em pauta na prática de contar histórias: uma atividade educativa incentivada nas bibliotecas escolares da Grande Vitória, Espírito Santo, Brasil

temporal, que deram fibra e contextura a esse construto teórico:

\section{Quadro 1 - A arte de contar histórias e o panorama cronológico}

\begin{tabular}{|c|c|}
\hline \multicolumn{2}{|r|}{ Configuração interdisciplinar e histórica - histórias narradas, contadas, cantadas... } \\
\hline 离: & $\begin{array}{l}\text { Contar histórias é uma arte que remonta à época do surgimento do homem há milhões de anos - têm } \\
\text { origens na tradição oral e existem desde o começo dos tempos, há pelo menos } 30.000 \text { anos, as pinturas } \\
\text { rupestres mostram homens sendo perseguidos por touros na França e histórias orais na Austrália. }\end{array}$ \\
\hline 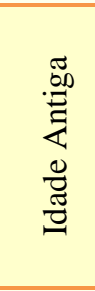 & $\begin{array}{l}\text { Antiguidade Clássica - Diógenes o mais folclórico dos filósofos, figura as histórias antigas. } \\
\text { Desde a Antiguidade, podemos encontrar narrativas que envolvem tapete e oralidade, têxtil e texto, } \\
\text { como o mito grego de Filomena (séc. v a.C.). A figura do narrador oral são os bardos responsáveis } \\
\text { pela transmissão de histórias, lendas e poemas orais na forma de canções. Quanto mais desconhecido } \\
\text { era o mundo em que se vivia, maior necessidade se tinha de povoar este universo com imagens que } \\
\text { pudessem educar e fortalecer a coragem, predispondo a arte de se enfrentar monstros, dragões e } \\
\text { demônios. }\end{array}$ \\
\hline 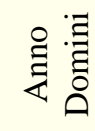 & $\begin{array}{l}\text { Jesus profetiza e protagoniza com histórias - o 'bom samaritano', o 'filho pródigo', o 'rico e do } \\
\text { Lázaro' o 'devedor sem compaixão'. Assim nenhum profeta fez tanto uso das parábolas de fé. Até } \\
\text { Richard Dawkins (etólogo) ressalta que Jesus deve ter sido o maior contador de histórias. }\end{array}$ \\
\hline 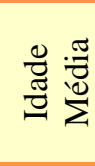 & $\begin{array}{l}\text { Idade Média - Contador era respeitado em todos os lugares por onde iam, os trovadores obtinham } \\
\text { entrada em palácios e aldeias contando histórias do gosto popular - Idade Média. } \\
\text { Era medieval - contador está muito presente nos castelos tantas vezes sombrios, as narrativas eram } \\
\text { tecidas pela voz mágica do contador em criar uma atmosfera de intensa magia. }\end{array}$ \\
\hline 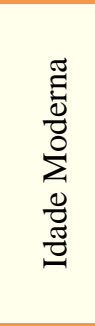 & $\begin{array}{l}\text { Século XV - as manifestações literárias, tradição mais rudimentar do que se pode denominar a fábula } \\
\text { indiana de expressão sânscrita, já que é possível estudá-la por meio da coleção de Vishnu Sarma } \\
\text { chamada Panchatantrã, uma antiga escrita de coleções de fábulas do mundo. } \\
\text { Século XVI e XVII - no Oriente Médio o narrador profissional de narrativas e de grandes coleções } \\
\text { de contos de fadas indianos e turcos faz parte da educação dos príncipes. } \\
\text { Século XVIII - griot (ou griô) propaga o olhar para uma tradição que valoriza a oralidade, a palavra } \\
\text { e a história de seu povo. Com histórias os griots educam e encoraja seu povo, alimentando a memória, } \\
\text { na África os griôs são mestres em ensinamentos \& tradições. }\end{array}$ \\
\hline 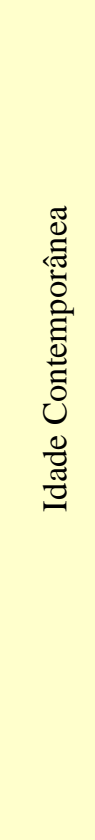 & $\begin{array}{l}\text { Século XX - Monteiro Lobato e Malba Tahan apontam que todos os povos civilizados ou não, usaram } \\
\text { as histórias como veículo de verdades eternas - e isso conserva e difundi tradições. } \\
\text { Década de } 1970 \text { - nos Estados Unidos, muitos narradores tornaram-se profissionais da literatura oral. } \\
\text { Surge o National Storytelling Network em 1976, a maior associação dedicada a promover narrativas. } \\
\text { Na década de } 1970 \text { - surge num movimento renouveau du conte, a arte de contar histórias que } \\
\text { conquista o seu espaço na campanha pela revalorização das culturas fundamentadas na tradição oral } \\
\text { e cênica. } \\
\text { Década de } 1980 \text { - ressurge a figura do contador de histórias, ou o professor/contador de histórias, e a } \\
\text { sua importância no âmbito educacional e emocional das crianças, com presença certa em bibliotecas, } \\
\text { feiras de livros, livrarias e escolas. } \\
\text { Década de } 1990 \text { - } 20 \text { de março é marcado como o Dia Internacional do Contador de Histórias; as } \\
\text { raízes (Suécia) do evento vem de } 1991 \text { - O dia de Todos os Contadores de Histórias. E na década de } \\
\text { 1990 - Storytelling - ferramenta de comunicação digital começou em 1993 a ser estudada nos EUA, } \\
\text { quando Joe Lambert lançou o estimulante projeto 'American Film Institute'. } \\
\text { Século XXI - aconteceu no Canadá (2007) um festival em Newfoundland e, o dia } 20 \text { de março de } \\
\text { 2008 foi marcado na Holanda como o evento Vertellers no de Aanval' com a aparição repentina de } \\
\text { contadores de histórias em sala de aula. } \\
\text { Década de } 2010 \text { - Livro Storytelling de Carmine Gallo (lançado em 2019) que revela a arte de contar } \\
\text { histórias, descrevendo Steve Jobs, papa Francisco, Churchill e outras lendas da liderança. O autor diz } \\
\text { que os Storytellers são realizadores de sonhos: 'Eles não só alcançaram as estrelas, como motivaram } \\
\text { o resto de nós a criar os próprios projetos'. }\end{array}$ \\
\hline
\end{tabular}

Fonte: os autores, com base em Luciano (2014), Café (2015) e Vicente (2015).

Sendo assim, o percurso histórico (Quadro 1) se completa com uma geração de jovens contadores de histórias - como Renée Robitaille, Éric Gauthier e Fred Pellerin. Esses 
profissionais visionários buscaram expandir a narrativa para o público (no Quebec, Canadá) e em festivais, bibliotecas e escolas - conclamando que essa é uma arte tão antiga quanto particularmente moderna (GREENHILL, 2020). Daí pergunta-se: para onde estamos caminhando? O que vem sustentando novas formas de atuação profissional? Quais as competências hodiernas e quais as perspectivas desta prática em 2030? Em 2050? Serão novos patamares? Quais os protocolos discutem a retomada (reabertura, rumos) das bibliotecas póspandemia? E os desdobramentos no mercado de trabalho pós-covid-19?

O conto de tradição oral atravessou séculos, passando de geração em geração, servindo de inspiração a estudiosos para a escrita e publicação de contos infantis. Entre os povos ancestrais, eles promoviam momentos de união, confraternização e trocas de experiências. Grosso modo, o Ser humano conta inúmeras histórias e, desde o início do desenvolvimento das habilidades de comunicação e da fala há algo a se contar e um rol de dilemas envolvendo a desinformação, fake news e pós-verdade. Assim, a contação de histórias também amparou os povos antigos há passarem o tempo e a vencer o tédio.

\subsection{O Âmago do bibliotecário e outras tessituras além do 'Conto da Carochinha'}

A contação de história é um neologismo criado nas últimas décadas do século XX, aponta Busatto (2005). Para a pesquisadora tal expressão se refere ao ato de contar ou narrar histórias - e ambas as palavras "querem dizer a mesma coisa" (BUSATTO, 2005, p. 7). Assim, a transmissão de informações através da contação de histórias se vale de múltiplas manifestações do universo oral, o que possibilita a movência - isto é o tempero que agrega a tradição oral e serve para perpetuar as lembranças e vivências que são atinentes à dimensão coletiva, interpessoal e individual dos sujeitos envolvidos.

Souza (2017) assinala que na boa contação de histórias se obsecra: i) o silêncio do ouvinte, a voz do ouvinte cala para que o texto possa abrolhar sentidos e, um texto provoca muitos sentidos que no transcursar da contação se relevam ao ouvinte; ii) nos olhos e os ouvidos do leitor estão os sentidos que lhe permitem abstrair, construir conceitos e hipóteses, brincar com o texto, aprender e internalizar significados, exteriorizar emoções; iii) é pelos sentidos que o texto é recebido e é por meio deles que o leitor constrói a lógica do enredo ficcional

Já Almeida (2014) assevera que nas diversas fases da trajetória histórica se percebe a complexidade e variabilidade das expressões (regionalismo na cultura e literatura do Brasil) 
O bibliotecário em pauta na prática de contar histórias: uma atividade educativa incentivada nas bibliotecas escolares da Grande Vitória, Espírito Santo, Brasil

que revelam o processo de humanização; e assim, destaca que:

Das experiências vividas [...] nasce no ser humano o dom de transmutar-se. Despertam-se ideias, avolumam-se desejos, rompem-se barreiras, abre-se um veio de inesgotáveis possibilidades. O homem adquire, pois, condições de pensar, de modificar situações, de criar novos paradigmas, de projetar seu imaginário na concretização de ações fomentadas por seus sonhos e [...] A fala articulada pode considerar-se deflagradora da legítima ascensão intelectual da humanidade. O homem só cresce quando em contato com o outro homem. [...] Por meio da comunicação, une indivíduos, constrói pensamentos, incrementa discussões, diferencia juízos, alarga as fronteiras do conhecimento e aprimora o burilamento do espírito. Educar não é tão somente ensinar. Buscando-se a raiz da palavra, provinda do latim educère (conduzir), compreende-se que o ato de educar merece revisão. Revisão essa que os educadores, ou assumem como um compromisso de renovação de pressupostos para a consecução de uma postura pedagógica compatível com a contemporaneidade, ou será inócua (ALMEIDA, 2014, p. 28).

Nesse aspecto de diagnóstico, acredita-se nas responsabilidades pedagógicas (e missão) do bibliotecário escolar de despertar a cidadania. Dessa forma, o recurso de comunicação de rodas de leitura e a contação de histórias abrem a imaginação e trazem para a criança o contato com importantes elementos da prática leitora e do ser ouvinte. Isso permite observar que a prática da narra de histórias de certa forma pauta reflexões acerca das condições de produção de sentidos e leitura de mundo - uma vez que esta (cognição) precede à leitura.

Contudo, para que isso aconteça, é preciso à responsabilidade e a sensibilidade para saber contá-las. Assim, narrar ou contar ou cantar histórias é criar um ambiente de experimentação/descobertas (ação e observação), surpresas/provocações, suspense/emoção, no qual a trama e as personalidades adquirem tônus e pulsões, transformando os interagentes (tanto o narrador como o ouvinte).

Sobre o tema, Knoche (2013), afirma que:

Pode-se dizer que o ato de ler ou ouvir histórias possui função terapêutica, pois é por
meio da fruição literária e contos que os indivíduos podem adquirir o entendimento
acerca de valores, do mundo, dos outros, bem como a si próprios. A leitura liberta
estimula o imaginário, auxilia em novas descobertas, agrega conhecimentos, amplia
horizontes, desenvolve o raciocínio lógico, amplia o vocabulário e a capacidade de
comunicação, entre tantos outros fatores benéficos. [...] Assim, a contação e leitura
em voz alta de histórias praticadas por agente promotor da leitura, ou no caso por
profissional ou acadêmico do curso de Biblioteconomia, aliadas a brincadeiras, que
são mais uma das possibilidades de entretenimento, podem proporcionar momentos
de prazer, alegria e descontração ao bem-estar humano. Essas práticas culturais além
de favorecer o externar dos sentimentos e emoções reforçam a identificação, o respeito
para com o outro, libertam a imaginação e a criatividade, podendo transformar não
tão somente o ouvinte, mas também o próprio agente responsável por tais ações.
Sendo esta experiência para alguns, fonte inesgotável de pesquisa e prática, traduzida
em carinho, sensibilidade, cidadania e responsabilidade social (KNOCHE, 2013, p.
576-594).

Há também as histórias curativas, citadas pela médica e autora Susan Perrow - a qual trabalha histórias terapêuticas para comportamentos desafiadores. $\mathrm{O}$ potencial Bibl. Esc. em R., Ribeirão Preto, v. 7, n. 2, p. 17-41, 2021. 
genérico/curativo de determinadas narrativas pode ajudar ou curar situações específicas de comportamento (superar o trauma). Entende-se assim, que há varias táticas para a ação cultural/terapêutica do "transformar vidas" com histórias. O poder medicinal das histórias envolve os ouvintes e viabiliza ao contador a possibilidade de promover a mudança de comportamentos inadequados em diferentes idades e situações (MIHIĆ et al., 2017). Falar de histórias é apresentar uma medicação natural, homeopática - que têm a capacidade de restabelecer o equilíbrio.

Mihić et al. (2017) esclarecem que as histórias são potencialmente terapêuticas ou curativas e, os contos folclóricos ou de fadas expõem possibilidades salutares - sim, há neles a oferta de esperança e coragem para lidar com o hostil câmbio da vida. Logo, uma história faz rir ou chorar, ou ambas as coisas - a gargalhada e a lágrima, não importando seu conteúdo, tem propriedades, até mesmo, curativas. Logo, a contribuição dessa arte/atividade curativa é mostrar e permitir, contar, criar e trazer possíveis transformações para a humanidade. Contudo, alertam os pesquisadores, as histórias não são pílulas mágicas com receitas para cada comportamento (MIHIĆ et al., 2017) e a verdade é que só se faz empatia/einfühlung com inteligência emocional.

Nestas circunstâncias o(a) bibliotecário(a) tem o papel fundamental de repensar os serviços e ações para focalizar sua missão - construídas com a preocupação de que sempre informar, sem ambiguidade, deixando claro sua singularidade e seu compromisso com a comunidade que serve. Dessa forma, a contação de histórias conduz de modo lúdico, a mediação de informações e os conteúdos mantendo uma relação de coerência e complementariedade com o encargo do "todo", no caso, a educação. 
O bibliotecário em pauta na prática de contar histórias: uma atividade educativa incentivada nas bibliotecas escolares da Grande Vitória, Espírito Santo, Brasil

\subsection{Novas dinâmicas no cotidiano escolar: a oralidade que 'Não Está No Gibi'}

$\mathrm{O}$ ato de narrar histórias (oralidade, narrativas orais) é próprio do ser humano, e o profissional da informação pode apropriar-se desse atributo e transformar a contação em um importantíssimo recurso de formação do leitor (ROBSON, 2020). A ação de caráter lúdicocultural nas escolas é uma forma de envolver, divertir, expressar o imaginário e o desenvolvimento mental das crianças, e hoje vem ressurgindo a figura do bibliotecário contador de histórias - agente que possibilita o resgate da memória cultural e afetiva.

Narrar histórias instiga o gosto pela leitura/literatura, e desenvolve padrões relacionais (cognitivos emocionais e comportamentais) que são um cimento simbólico de comunicação e, que pode salvar vidas e minorar o sofrimento humano. Lourenço (2014) esclarece sobre os inumeráveis benefícios da leitura e, aponta ainda que a empatia promove coesão entre as pessoas e soa como uma valiosa prática de transmitir saberes e, portanto, isso colabora para as relações sociais. No próprio "espaço de leitura, entre o mediador e a audiência, expandindo-se também para outras dimensões da escola e dos grupos sociais em que esses sujeitos - contador e ouvinte - estão inseridos" (LOURENÇO, 2014, p. 30).

Lourenço (2014, p. 30) novamente argumenta que a oralidade pode formar leitores, valorizar histórias vivas, sensibilizando o ouvinte com o estímulo de percepções imaginárias que articulam o sensível e tocam o encantamento de mundo, alimentando o espírito, resgatando significados para a nossa existência. Além disso, narrativas orais ampliam o contato com o livro para que os discentes possam expandir seu universo cultural e imaginário e, através de variadas situações podem intrigar, fazer pensar, trazer descobertas, provocar o riso, a perplexidade, o encantamento etc. Ou seja, ao se contar uma história, percorre-se um caminho absolutamente infinito de descobertas e compreensão do mundo.

Assim, o "contato com uma história é um convite à imaginação e à brincadeira de fazerse protagonista, (re)contando a sua própria história em cenários imaginativos e encontrar resoluções criativas" (MENEZES et al., 2020, p. 4).

Vigotsky (2009) ressalta que o acúmulo de experiências é condição imprescindível (embora não suficiente) para o desenvolvimento da imaginação e esta é a cerne da atividade criadora, que por sua vez tem/deve ter papel basilar dentro da escola. Assim, avaliamos e enfrentamos e nos adaptamos (ou não!) à realidade que se apresenta. Desse modo, a perspectiva sociohistórica de Vygotsky (2009, p. 11) chama atenção para atividade (re)criadora do homem 
"aquela em que se cria algo novo", seja este um objeto ou alguma construção da mente. Tal atividade tem relação direta com a memória (reconstituição) porque reúne as lembranças e marcas do que já foi vivido, consistindo numa repetição ou reprodução de algo que já foi criado anteriormente.

O espaço da biblioteca torna-se então um local propício (locus creationis) a essa atividade literária, pois por ela circundam não só livros, mas igualmente as pessoas. Logo, as atividades de contar e ouvir histórias envolve a formação do leitor e assim se supõe que à hora do conto seja um momento de leitura e encantamento. Deste modo a contação de histórias expressa uma tênue celeridade que incita a imaginação e o trânsito entre o fictício-real da mediação literária, ou seja:

No nosso entendimento, [a contação de histórias] não é apenas um processo de
mediação literária, mas de formação de leitor. Por mais que o Bibliotecário não exerça
o papel de ensinar as crianças a lerem os códigos linguísticos, através da contação de
histórias, eles estão desenvolvendo a capacidade interpretativa do aluno e assim
contribuindo para o seu letramento. Esse é um trabalho transformador, que precisa ser
expandido, conhecido e principalmente, reconhecido [...] Por certo, apesar das
transformações sociais ocasionadas por novas formas de comunicação, o contador de
histórias ressurgiu como uma figura urbana que sobe nos palcos usa artifícios, mas
que não perdeu a força do olhar, da expressão e da tradição oral. Seu veículo
transmissor de conhecimento continua sendo a voz, marcando cada momento de
emoção da história e revelando as intenções do narrador (SOUSA; LIMA;
CAVALCANTE, 2017, p. 13-18).

Souza (2017, p. 20) destaca que a "contação de histórias é um elemento a mais para o ensino-aprendizagem, suscita o interesse dos indivíduos pelo conhecimento, o que se acredita ser um dos caminhos para melhorar a qualidade da educação escolar”. Assim, a contação de história excita a imaginar e a transformar - contribui na formação da personalidade da criança e no desenvolver da seara social e afetiva.

Nessa linha de pensamento, Bortolin e Burghi destacam:

Nossa defesa é que na escola, especificamente na biblioteca escolar as narrativas de
histórias precisam, cada vez mais, estarem presentes evidenciando uma diversidade
de textos, que devem ser oralizados de forma ética e afetiva. Na esteira de Paulo Freire
o fato de estar disponível, engrandece o ato de mediar, o mediador e, em consequência,
o espaço da biblioteca escolar (BORTOLIN; BURGHI, 2014, p. 217).

Silva, Silva e Lourenço (2016, p. 12) observam que "os caminhos que levam à formação do bibliotecário mediador são variados e diversificados, pois muitos obtiveram na própria experiência de vida". As pesquisadoras ainda destacam que existem cursos, oficinas e até mesmo disciplinas nas universidades que auxiliam nessa preparação profissional, e no caso dos bibliotecários a Classificação Brasileira de Ocupações assinala que o Moderno Profissional da 
O bibliotecário em pauta na prática de contar histórias: uma atividade educativa incentivada nas bibliotecas escolares da Grande Vitória, Espírito Santo, Brasil

Informação (MPI), entre outras coisas deve desenvolver recursos informacionais, disseminar informação e realizar difusão cultural e educativa - o que agencia novas iniciativas e, outros incentivos à mediação da leitura (SILVA; SILVA; LOURENÇO, 2016) o que situa a nova energia cinética da biblioteca no âmbito escolar.

Silva, Alencar e Bernardino (2017) apontam que:

\begin{abstract}
A valorização da contação de histórias na biblioteca escolar contribui para um desenvolvimento da aprendizagem, ampliando e estimulando o aumento do gosto pela leitura e os recursos auxiliares e criativos utilizados na contação de história mostrouse uma saída para colaborar com a promoção, estímulo e atração para Biblioteca Escolar, utilizando-se de elementos inseridos no contexto escolar, onde aplicados e explorados, proporcionará um ensinamento significativo através do encantamento das palavras (SILVA; ALENCAR; BERNARDINO, 2017, p. 20).
\end{abstract}

Sousa, Lima e Cavalcante (2017) reforçam que a memória social gera novos conhecimentos e o bibliotecário ajuda a preservar essa memória, o MPI, assim, lida com a preservação do patrimônio documental, artístico e cultural a partir da interface da informação e da memória. Portanto é possível existir novos saberes, que no percurso das experiências individuais se conecta a múltiplas vivências coletivas e, reconstroem o passado num entrelaço dos anseios do presente (SOUSA; LIMA; CAVALCANTE, 2017).

\title{
3. Caminhos teóricos e metodológicos
}

O caminho metodológico se funda na perspectiva qualitativa da pesquisa, e visa alcançar nos relatos de vida do bibliotecário contador de histórias, alguns dos sentidos que impulsionam a ação de contar ou cantar histórias. Dessa forma, parte-se do pressuposto de que as experiências vivenciadas pelo MPI no decorrer de suas trajetórias de vida se entrelaçam socioculturalmente com o ambiente lúdico e informativo da biblioteca escolar.

Assim, ao adotar uma perspectiva socioconstrutivista de Antunes (1999), esse estudo adentra numa perspectiva teórica que coloca o trabalho como uma atividade transformadora da natureza e subjetivada pelo "agente transformador da sociedade", e ainda, ao encontro dessa via epistemológica se frisa que o exercício profissional pontua um sentimento de retorno (abrir caminhos e oportunidades) que envolve o orgulho como dádiva gerada pela atividade (BOTTOMORE, 1988).

Bottomore (1988) aponta que o trabalho que aborda o Método Tradicional de Ensino pode ser percebido de formas variadas, mas sempre é direcionado a um objetivo específico que 
gera uma troca. Todavia, é importante ressaltar que o período de pandemia da Covid-19, foi um fator limitador para se aprofundar na metodologia 'história de vida' já que os profissionais com a interrupção de contrato de trabalho estavam se readequando a nova forma de atuação. A Covid-19 trouxe uma ressignificação aos processos capitalísticos, que vinham balizando os ecossistemas educativos nos mais diversos rincões e confins, atingindo a escala planetária, o que inclui o alerta máximo - no sentido do imperativo de emergência de um mundo mais ‘sereno e autopoético', pautado pela responsabilidade ecossistêmica.

Assim, mesmo com a pandemia, se buscou ancorar as entrevistas com os pressupostos da metodologia história de vida e as adaptações que o contexto impôs aos rumos dessa pesquisa com articulação feita com recursos das Novas Tecnologias de Comunicação e Informação (NTCIs).

No método história de vida, o interagente externaliza por meio da linguagem (narração) e de sua perspectiva pessoal às experiências vividas e os sentidos ou sentimentos (autoimagem, alegria, exultação, percepção, expectativas, frustrações, ânsias, silenciamento). Ao contar sua vida, o sujeito fala de seu contexto tornando-as, pelo tempo afora, infinitivamente acessíveis a novas provocações e abertas à tarefa de ressignificá-la. Por fim, com os relatos recolhidos se apresenta algumas possibilidades de interpretações e câmbios de comunidade.

Para Silva, Barros, Nogueira e Barros (2007, p. 29) alguns pressupostos são esenciais no que diz respeito ao método "História de Vida" e, dessa forma frisa-se que:

[...] o vínculo entre pesquisador e sujeito, a questão da relação estabelecida, o sentido que o sujeito dá para sua história, e sua ressignificação e condição do discurso é uma ponte entre o social e o individual [...] Assim encontramos a possibilidade desse sujeito de refazer sua trajetória, de reconstruí-la, atribuindo um novo significado ao seu caminho [...] Ao contar sua vida, o sujeito fala de seu contexto - fala do processo por ele experimentado, intimamente ligado à conjuntura social onde ele se encontra inserido. Ao se trabalhar o vivido subjetivo dos sujeitos, através do método de História de Vida, temos acesso à cultura, ao meio social, aos valores que ele elegeu e, ainda, à ideologia. [...] O método de História de Vida é um método científico com toda força, validade e credibilidade de qualquer outro método, sobretudo porque revela que por mais individual que seja uma história, ela é sempre, ainda, coletiva, mostrando também o quão genérica é a trajetória do ser humano (SILVA; BARROS; NOGUEIRA; BARROS, 2007, p. 29-34).

No campo da CI, o método história de vida tem sido utilizado por pesquisadores como Andrade e Melo (2017) e Carvalho, Nascimento e Bezerra (2018), que buscaram compreender a trajetória de vida a partir de uma leitura compreensiva, situando um construto em termos de proposições dialogais. De tal modo, Granato, Lopes e Costa (2020) advertem que o emprego da narrativa permite que o pesquisador torne 'visível e audível' as práticas e as atividades, os 
O bibliotecário em pauta na prática de contar histórias: uma atividade educativa incentivada nas bibliotecas escolares da Grande Vitória, Espírito Santo, Brasil

processos e características culturais, os fatos estruturais do cotidiano do mundo social - isto possibilita a construção de saberes sobre o processo de aprendizagem a partir dessas narrativas.

Assim, falar de história de vida como método é reportar um registro documental (da oralidade e mediação) que tem base em narrativas individuais de uma biografia, e isso é angariado por intermédio de entrevistas as memórias contadas por via de narrativas que situam os princípios informativos e estruturantes da análise (SILVA; BARROS; NOGUEIRA; BARROS, 2007, p. 29-34).

Participaram do estudo cinco profissionais com idade média de 35,4 anos (DP = 12,3), sendo quatro do sexo feminino e atuam ou atuaram como em uma ou mais bibliotecas escolares das Unidades Municipais de Ensino Fundamental (Umefs) da região metropolitana de Vitória, Espírito Santo, Brasil (RMGV-ES). Diante disso, o foco da pesquisa busca, pelo método história de vida, compreender e analisar o ato de 'contar histórias' na trajetória de alguns bibliotecários que trabalham nas bibliotecas das escolas investigadas - Umefs da RMGV (municípios de Cariacica, Fundão, Guarapari, Serra, Viana, Vila Velha e Vitória).

Portanto, esse diagnóstico de pesquisa com os bibliotecários escolares da região metropolitana da RMGV, que utilizam a contação de histórias no seu campo de atuação, aconteceu no mês de julho de 2020, procurou tecer entrevistas semiestruturadas online, via Email e WhatsApp, utilizando a metodologia de história de vida para se compreender as interações e mediação do MPI no que tange a contação de histórias na ambiência da biblioteca escolar.

Para manter o sigilo do nome dos respondentes, optou-se por utilizar nomes fictícios inspirados nos 'cinco interagentes' que personificam a proteção da humanidade - Tierra, Fuego, Viento, Aqua e Corazón - e pela união desses poderes temos o Captain Planet (super-herói estadunidense da década de 1990). Assim, foram coletadas cinco narrativas com a abordagem História de Vida, situando alguns aspectos em comum, ressaltando que os contadores de história selecionados são bibliotecários, bacharéis formados na Universidade Federal do Espírito Santo - UFES na última década do século XXI e, que atuam em bibliotecas escolares das UMEFS na RMGV. 


\section{A práxis: 'nós somos parte da rede de que são feitos os sonhos'}

O contar história é uma prática cada vez mais presente na escola. Ora se desenvolve a partir do bibliotecário, ora a escola recebe a visita de um contador, ora ela permeia os espaços culturais (como feiras do livro), ou até mesmo o professor em sala de aula. A interação bibliotecário/professor multiplica o pautar da literatura para além da sala de aula.

A questão da contação de histórias como participante da práxis pedagógica pode servir de elo no processo dialógico, um intercâmbio constante - constitui-se do mesmo tecido e tessitura de que são feitos os sonhos.

\subsection{Principais resultados da pesquisa: abram-se as cortinas}

O cenário da investigação frisa a arte de contar história e vai ao encontro das teorias de Vygotsky, o qual reporta que em nossa "atividade nada se cria de novo" e a base de tudo é a repetição mais ou menos precisa daquilo que já existe (VYGOTSKY, 2009, p. 12). Sobre as vantagens da contação de histórias destaca-se: a aprendizagem de conteúdo, a socialização, a comunicação, a criatividade e a disciplina. Além disso, contar histórias é uma alternativa para que os alunos tenham uma experiência positiva com a leitura.

Dessa forma, os entrevistados destacam que já é uma tarefa rotineira escolar e, nos relatos de história de vida resgatamos oito tópicos mais relevantes para os entrevistados, quando questionados sobre a 'essência' da contação de histórias, e assim a ilustração a seguir (figura 1) apresenta percentagens cernes da pauta: 
O bibliotecário em pauta na prática de contar histórias: uma atividade educativa incentivada nas bibliotecas escolares da Grande Vitória, Espírito Santo, Brasil

Figura 1 - Sondagem da fala dos entrevistados, coisas que alvidra e ecoa nas arguições

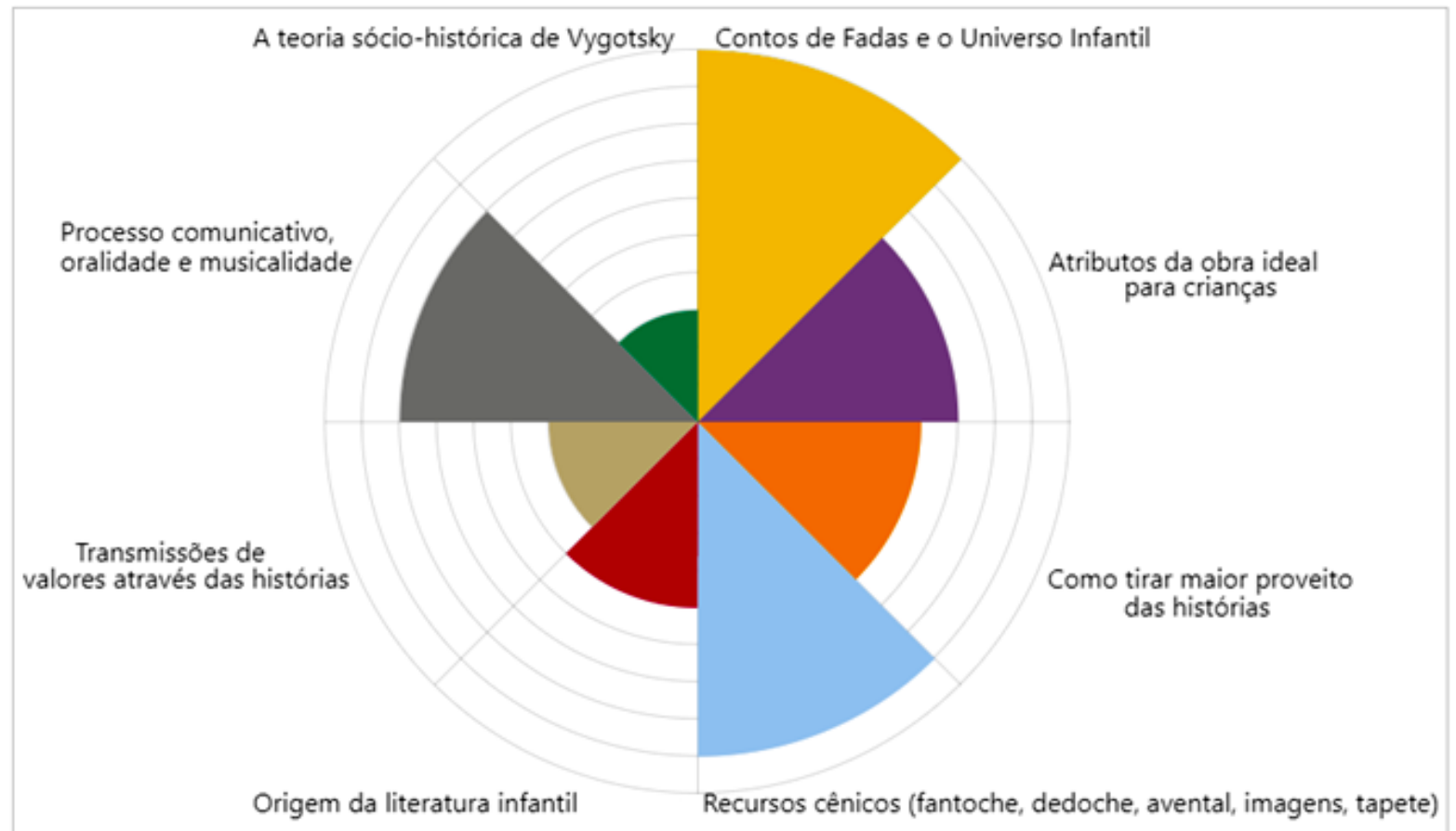

Fonte: os autores, resultados da pesquisa 2020.

A narrativa de contos de fadas e o painel cênico são apontados como pontos principais para o âmbito efetivo de um trabalho na biblioteca escolar, mas a fala dos entrevistados destaca o valor da oralidade, musicalidade, poética e outras mixagens significantes que deve fazer sintonia com os atributos da obra e a faixa etária do discente. Nessa via, autores como Charles Perrault, Hans Christian Andersen e os irmãos Jacob e Wilhelm Grimm, se tornaram nomes de referência para se apresentar a literatura infanto-juvenil, o mundo encantador de histórias, e a ação de narrar histórias no espaço escolar enriquece a prática docente e a missão bibliotecária em torno de aprendizagens múltiplas.

Grosso modo, a rede de bibliotecas não pode ter um papel passivo perante as demandas da comunidade escolar, ela precisa ser um núcleo de troca de experiências, ativadora de sensibilidades, protagonista de interações saudáveis entre os profissionais da escola e o corpo discente (alunos participativos do processo de ensino e aprendizagem) arguem os entrevistados (Bibliotecárias) Tierra, Fuego, Viento, Aqua e Corazón.

Em suma, os bibliotecários escolares ao se movimentar pela filosofia africana Ubuntu tornam viável falar que a convivência é feita de entrelaçamentos sociais, com relações éticas e responsáveis faz-se a ativação de autopoiese. E assim se segue narrando e tentando, e também acreditando numa Era mais lúdica e autopoiética, com seres e saberes entrelaçados.

Destarte, coletadas cinco narrativas com a abordagem história de vida se destaca um 
painel síntese (Quadro 2) de entrevistas (110 minutos aprox.) com cada um dos entrevistados.

Quadro 2 - A contação de histórias atividade comunicativa e principais leituras

\begin{tabular}{|c|c|}
\hline & Depoimentos - interagentes que atuam em biblioteca escolar \\
\hline 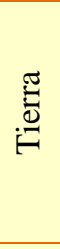 & $\begin{array}{l}\text { Bibliotecária (37 anos) [...] Eu conto muitas histórias, mas não aprendi na graduação [...], participei } \\
\text { do 'Gechufes' (Grupo Experimental de Contadores de Histórias da Ufes) e curso de contação de } \\
\text { histórias na Prefeitura Municipal de Vitória-ES. Os livros legais que contei são: Tinha uma velhinha } \\
\text { que engoliu uma mosca de Jeremy Holmes, Menina bonita do laço de fita de Ana Maria Machado, } \\
\text { que também adaptei para uma peça teatral com os alunos, Adivinha quanto eu te amo de Sam } \\
\text { McBratney, O gato Massamê e aquilo que ele vê da Ana Maria Machado e Chapeuzinho amarelo. }\end{array}$ \\
\hline $\begin{array}{l}8 \\
800 \\
\stackrel{0}{\vec{I}}\end{array}$ & $\begin{array}{l}\text { Bibliotecária (56 anos) [...] me interessa os contos como a Insurreição do queimado, os Contos de } \\
\text { enganar a morte, aquele que diz 'No meio da noite escura tem um pé de maravilha', e também a obra } \\
\text { A ilha dos sentimentos, Narizinho e o príncipe escamado. Assim, aprendi a contar historias nas } \\
\text { formações que tive ainda como estagiári@ na prefeitura [Serra] [...] Não fiz cursos, apenas cursei } \\
\text { uma disciplina no curso de Letras [segunda graduação] no IFES e as experiências são em lugares um } \\
\text { tanto diferentes, os primeiros aprendizados foram o lar e a igreja. }\end{array}$ \\
\hline$\stackrel{\stackrel{0}{\Xi}}{\stackrel{0}{>}}$ & $\begin{array}{l}\text { Bibliotecária ( } 31 \text { anos) [...] Os livros mais interessantes para mim são: No meio da noite escura tem } \\
\text { um pé de maravilha, do autor Ricardo Azevedo, outro chama Pato! Coelho! Dos autores Krouse } \\
\text { Rosenthal e Lichtenheld, e também a obra 'Chapeuzinhos coloridos' de José Roberto Torero e } \\
\text { Marcus Pimenta, e ia me esquecendo, poxa! Têm o livro 'Quero meu chapéu de volta' do Klassen } \\
\text { [...] Eu contei muitas histórias, por incrível que pareça é difícil eu citar todos os livros que eu contei } \\
\text { e eu criei outras tantas histórias [...] Já fiz cursos na biblioteca de Vitória, na UFES e na internet, pois } \\
\text { histórias é importante e reproduz a própria essência da vida e o Ser humano [...]. }\end{array}$ \\
\hline$\underset{\mathbb{Z}}{\stackrel{\pi}{Z}}$ & $\begin{array}{l}\text { Bibliotecária ( } 25 \text { anos) eu gosto de fazer histórias, de criar, mais tem livros que eu achei que foram } \\
\text { referência, que foi o Bumba Boi de Fabiana Ferreira Lopes, que é um livro muito legal, e outra } \\
\text { referência para mim também é o livro Congo Capixaba, eu já contei na escola, [...] da artista Márcia } \\
\text { Zanandréia - Cultura Popular do Espírito Santo, livro que eu gostei bastante [...] reverencio a obra } \\
\text { de Monteiro Lobato que é uma das referências que eu estou usando na biblioteca para trabalhar com } \\
\text { os alunos [...] Gosto da escritora capixaba que escreveu Ciça, da autora Neusa Jordem Possatti, os } \\
\text { livros da coleção Ciça são muito bons! [...]. }\end{array}$ \\
\hline 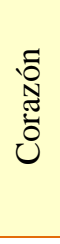 & $\begin{array}{l}\text { Bibliotecária (28 anos) [...] os livros mais atraentes e marcantes são 'A Criança Mágica' da Lilian } \\
\text { Menenguci, o de Lendas Capixabas, que tem uma lenda adaptada pela professora Meri Nadia [Dra } \\
\text { na UFES] } O \text { pássaro de fogo, esse me marcou muito, o livro Chapeuzinhos Coloridos, me marcou } \\
\text { bastante também porque reconta uma historia clássica sobre outras óticas, a obra 'O cabelo de Lili' } \\
\text { que é da Lilian Menenguci, e é também uma lembrança da minha atuação em Vila Velha e gosto de } \\
\text { Contos dos Irmãos Grimm e Hans Christian Andersen a Caixinha de Fósforo [...]. }\end{array}$ \\
\hline
\end{tabular}

Fonte: os autores; resultados da pesquisa, jul. 2020.

Ao utilizar a contação de histórias em bibliotecas faz com que todos saiam ganhando, tanto o discente, que será instigado a imaginar e criar, quanto o bibliotecário/professores, que tornaram o ambiente da biblioteca mais agradável e produtivo, promovendo a aprendizagem significativa. De tal modo, é no seio da atividade narrativa que surge o reencontro de experiências transmitidas de indivíduo para indivíduo; 'Aqua’e Tierra, por exemplo, articulam histórias e a comunidade escolar:

Aqua Bibliotecári@ (25 anos) [...] Gosto muito de contar histórias de folclore, lendas, adivinhas, cordéis encantados [...] a contação é importantes para mim e para os outros que ouvem e interagem. Na maioria das vezes não uso nada, mas adaptei várias histórias e escrevi outras tantas [...] histórias que adaptei são: O Gênio do Penedo e Pedro Cem, e escrevi O vaga-lume da Vila [...] (AQU@, 2020).

Um conto inovador foi o do autor Eduard Jose, a obra E Júlia tem uma estrela, conta um segredo que a Julia tem uma estrela [...] a mãe de Julia doente falece [...] contei

Bibl. Esc. em R., Ribeirão Preto, v. 7, n. 2, p. 17-41, 2021. 
O bibliotecário em pauta na prática de contar histórias: uma atividade educativa incentivada nas bibliotecas escolares da Grande Vitória, Espírito Santo, Brasil

esta história na semana do dia das mães, alguns acharam tristes, outros [alunos] do quarto ano gostaram, a professora achou bacana e fez um trabalho com eles na sala de [...] O que me motivou a contar histórias foi o meu amor pelos livros/leitura e a atenção, carinho que vem de retorno, isso não tem preço (TIERR@, 2020).

$\mathrm{Na}$ entrevista com os bibliotecários contadores de história é possível destacar alguns cenários, e ademais, se ponderar sobre os silêncios e paixões, as falhas de memórias, a linguagem não verbal e, outros atos que compõem os dados de análise, as quais são destacados a seguir:

Viento Bibliotecária (31 anos) [...] [Como aprendeu a contar histórias?] Eu não sabia e foi uma coisa que me pegou de surpresa, nunca fiz curso, nem nada, é uma coisa minha, eu sempre gostei de teatro, eu sou compositor, músico e tive as bandas de rock, eu me via como interprete também à frente, porque eu era o vocalista e influenciador [...] acho que histórias estimulam a criatividade e a imaginação, o raciocínio e a lógica, então é muito importante, isso só faz a gente pensar o quão o nosso trabalho e admirável [...] gosto de criar histórias [...] de piratas, e fiz músicas inclusive dessa temática [...] penso na prainha de Vila Velha, eu fico imaginando as embarcações chegando ali, e o Vasco Coutinho, muita pirataria, coisa lendária, mistérios e tesouros, papagaios e naus [...] as crianças amam isso porque as histórias de piratas tem coisa mágica: a descoberta e Oasis, uma miragem que perpassa por várias emoções ao aluno, e é a tal questão do desbravar, do sair à luta [...] Costumo dizer que o caminho do sucesso tem riscos e tesouros, tem um baú e joias, e tudo mais que os bibliotecários sonham - os saberes, o bem social, a humanidade (VIENTO, 2020).

Corazón Bibliotecária (28 anos) [...] Eu nem sabia que isso seria um trajeto profissional, foi uma coisa que descobri no meu cotidiano, e fiz só um curso online de narrar histórias [...], contudo a prática é bem diferente porque cada turma demanda uma atenção, uma forma diferente de agir [...] eu tive muita influência da minha mãe que é professora aposentada pela rede de Vitória e que tinha o costume de me contar histórias, meu pai também, então fui influenciada pela família [...] Contar histórias envolve diálogo entre o ouvinte e o leitor, seja ele um ancião nas tribos indígenas, ou os griôs nas tribos africanas, e isso cria laços, você consegue desenvolver relações socioafetivas [...] nessa relação relembro da formação que a gente teve com a Lilian Menenguci, aconteceu que eu estava com a turminha de terceira série na biblioteca, e era uma turminha muito bagunceira, e a biblioteca parecia um furacão passando ali [...] e eu estava com o projeto de ler as 'Lendas Capixabas' para eles e ninguém me ouvia [...] então me sentei no chão, todos eles pararam o que eles estavam fazendo e olharam para mim com os olhos arregalados, tipo 'oh a tia sentou no chão!' e assim vi que naquele momento eu consegui prender a atenção deles - sai do patamar 'A Bibliotecária' para o status 'professora da biblioteca', sendo uma criatura leitora igual a eles, ao sentar no mesmo chão, assim consegui construir o solo que precisava. [...] Contudo, não me lembro de algum livro que eu tenha contado a história de modo adaptado. Não sai da graduação preparada para ser contadora de histórias, mas a demanda da profissional na biblioteca escolar me fez contar histórias, então eu fui aprendendo na marra e, nessa medida, vieram às experiências com as crianças e adultos. Assim fui gostando cada vez mais e faço com amor e paixão! (CORAZÓN, 2020).

Visto a relevância da contação de histórias na escola, a opção pelas entrevistas como base metodológica para este trabalho vai ao encontro a essa tendência: a voz que protagoniza essa pesquisa deve ser a voz dos contadores de histórias e é claro os bibliotecárias - Fuego e Tierra - assim destacam a hodierna era (associada à pandemia da Covid-19). 
Fuego Bibliotecária (56 anos) [...] Contar histórias é importante porque contribui com o fomento à leitura, estimula a imaginação, e colabora para a formação de pessoas mais humanas e conscientes do seu papel na sociedade [...] $\mathrm{O}$ momento do novo coronavírus é particular e desafiador para mim ao contar a história na web, no meu canal do YouTube, o aluno se envolve e a traz para o seu mundo, ali eu vejo que aquela história fez alguma diferença nesse tempo de tantos desafios e isolamentos [...] Hã?! O único instrumento que utilizei até hoje foi o livro e o que me motiva a contar história é saber que de alguma forma ela fará diferença para a vida de alguém [...] As adaptações que ocorreram foram na hora da contação, ao esquecer um trecho, costumo improvisar [...], ou seja, nenhuma oportunidade de história é perdida [...] teve uma história que gosto muito de narrar é A pulga e o Jesuíta, do autor capixaba Pedro Nunes, que fala da criação da igreja Reis Magos em Nova Almeida e contei tal história para os alunos dos quintos anos junto com atividade [...] E mesmo adaptando - a história era muito longa - não prendeu a atenção. Então ficou de aprendizado e experiência, não contar histórias longas ou tediosas ou a eterna arte de reaprender se faz e tecer com preparo. Tem muitas histórias que marcam e tocam as pessoas [...] e é necessário preparação para trazer as historias e, não dá pra ignorar que a doença Covid-19 trouxe diversos desdobramentos que marca e toca a vida e a memória da nação brasileira [...] (FUEGO, 2020).

Tierra Bibliotecária (37 anos) [...] Sempre gostei de ler e contar histórias e aprendi a ler com os gibis [...] Cara meu primeiro livro foi 'A ilha perdida' da Série Vagalume e contei para meus filhos, e hoje para os netos e alunos [...] depois quando passei em Biblioteconomia na UFES, estagiei na Biblioteca e Centro Cultural Carlos Correia Loyola em Valparaiso [Serra] e lá fiquei responsável pela ala infantil, contava histórias no auditório da biblioteca utilizando fantoches e cartazes, me vesti de bruxa e da boneca Emília. Depois fui trabalhar em Vila Velha, continuei as histórias de acordo com a série das turmas que recebia [...] Participei do curso de contadores de histórias Gechufes [UFES] e curso de contadores na Biblioteca Adolfo Poli Monjardim no centro de Vitória. [...] Contar histórias para as crianças e até para os adultos, se torna algo significativo nessa era pandêmica [...] E a história que mais chamou a atenção dos alunos é a da 'Velhinha que engoliu uma mosca', por ser uma história de repetição, eu ia contando e os alunos iam falando os nomes dos bichos que a velhinha engolia [...] e contei essa história até em aniversário de sobrinhos! [...] E outra historia que lembro é uma especial para a turminha de primeiro ano, contei a história da 'Menina Bonita do Laço de Fita', e nessa interação [...] a parte em que o coelhinho falava 'menina bonita do laço de fita qual é o seu segredo para ser tão pretinha?' Eles repetiam comigo [kkk, risos] e a gente fez um alvoroço [...] nunca tive habilidades musicais, mas gostaria sim de ter aprendido a tocar um violão, e recursos de mágica para ter uma melhor atuação [...] [destaca]. Teve uma história que gosto muito de narrar e que muito me marca é a 'Menina bonita do laço de fita', pois eu fiz uma peça teatral com alunos da escola, e adaptei durante ensaios na biblioteca, confeccionei o cenário e apresentei para as turmas e para os pais, foi sucesso total! [...] [E como a pandemia afeta o contar histórias?] O momento da pandemia é o do mais crucial ponto de inflexão da história mundial, observo que afetar profundamente o sistema educacional e todas as profissões [pausa, silencia-se] E valha-me Deus!? Não tem ponto de fuga, mas a válvula de escape para ver, ouvir, produzir, expor e narrar história é a internet; os canais do YouTube servem para compartilhar vídeos, também os postcards avançam para ajudar e a expandir a rede de contadores de história pelo planeta. (TIERRA, 2020).

Alguns narradores utilizam ferramentas sonoras e visuais, entre objetos que compõem seus personagens ou que ilustram suas histórias, já outros passaram por algum tipo de "mutação" no modo pelo qual transmitem a história e acabam optando em usar seu próprio corpo e voz como elemento para enquadrar à narrativa dizem as (os) Bibliotecárias Tierra, Fuego e Corazón. 
O bibliotecário em pauta na prática de contar histórias: uma atividade educativa incentivada nas bibliotecas escolares da Grande Vitória, Espírito Santo, Brasil

Adentramos, assim, em novos dilemas/patamares e cabe ao pesquisador interessado descortinar os estratagemas de narrar histórias, fazendo esse universo erigir tantas e distintas respostas em seus pleitos de pesquisa. Daí responde-se que sempre estamos caminhando para a transformação e nada será como antes. O espaço da biblioteca visa a atividade literária e o ato contar história é fonte de prazer, conhecimento e emoção. Isto engloba o lúdico e o decodificar da ação cultural oferta tônus a formação contínua de alunos leitores.

Destarte, a oralidade é portadora de significados para a prática pedagógica e sua função é despertar a imaginação e sentimentos, trazer alguma mensagem que transmite, resgata ou transcende o texto e a palavra. Quando o contador optar por usar apenas 'o poder da palavra' ela passa a ser mais do que simplesmente a fala. Ela passa a ser 'carregada de significados' (SOUZA, 2017); e, isso também é reportado pelas Bibliotecárias escolares.

\section{Cercando um 'Gran Finale'}

A fartura vem da riqueza do alimento e a confeitaria do momento, Trazendo a delicadeza e destreza do amor que flui na correnteza [...] na escola ou / na cidade, / sem maldade. (RONCHI, 2020, p. 88).

Viver ou narrar eis a questão? E porque não juntar ambas? E toda dor, diz Hannah Arendt (uma das principais pensadoras da filosofia política do século XX), pode ser suportada se 'sobre ela puder ser contada uma história'. Destarte, histórias transformam a vida e a humanidade! Nesse panorama, arredada a vertente da antropologia sartreana (existencialista), o escopo da pesquisa situa algumas apreensões sobre o elemento 'contação de histórias' na trajetória de cinco bibliotecários - contadores de histórias - atuante e protetores da biblioteca escolar.

O escopo deste estudo ao analisar e compreender como se situam a ação cultural de 'contar de histórias' na trajetória profissional de alguns bibliotecários, atuantes em Umefs da RMGV. De tal modo, a escolha dos profissionais entrevistados não ocorreu tendo como objetivo alcançar uma representação generalizada da categoria bibliotecária, mas na busca de elucidar algumas vivências, práticas e competências que trazem à luz uma socioconstrutivista contribuição a essa temática.

Frisa-se que o contar histórias é um dos hábitos ou práticas mais remotas que se tem assentamento na humanidade. Já a contação de história nas escolas é uma forma de instigar a imaginação e a criatividade das crianças, além de expressa e situar um incentivo a leitura e 
aprendizagem ao longo da vida. Assim, ressurge a figura do contador de histórias como profissão que além de incentivar a leitura exercita o multi-disciplinary insight (compreensão intuitiva precisa de uma causa e efeito).

A ação de contar histórias tem um fixo compromisso: ser o liame da construção dos elementos da cultura de nossa época, não podendo ignorar que a produção, difusão e intercâmbio da literatura é uma marcante particularidade para se pensar a cibercultura e as convergência tecnológica. Com as histórias narradas é possível traçar um painel de preservação e memória, estimular a imaginação, retratar pessoas e personagens, tonificar lugares e acontecimentos para favorecer os processos da aprendizagem ao longo da vida - inúmeras são as possibilidades e transições citadas pelos entrevistados (Bibliotecárias) Tierra, Fuego, Viento, Aqua e Corazón.

Assim, no estudo se verificar algumas maneiras de como a contação de histórias, utilizada como uma ferramenta auxiliar de trabalho para bibliotecários e provoca benefícios nos interagentes. As conexões (bibliotecário X oralidade) buscam reduzir o sofrimento psicológico desse momento tão duro da Covid-19; e sobre os aspectos éticos inerentes à assistência oferecida, o que a pandemia do coronavírus pode nos ensinar? Os profissionais têm essa questão em pauta e, assim reporta-se que na contação de histórias origina de um conjunto de práticas ecológicas, informacionais e planetárias para lidar como o novo.

Os resultados da pesquisa fornecem implicações práticas para aqueles que trabalham com a temática, na medida em que o "corpo e a voz, o mediar de informação e a intraconexão de protagonistas se transmuda em diferentes temporalidades; todavia gera o empoderar do sujeito e da instituição na acelerada vida moderna" cita o/a profissional 'Fuego'. Essa exposição, de certa forma, remete a inquietação de como será a reabertura das Umefs e das bibliotecas. A biblioteca da Umefs situa um lugar central de construção de conhecimentos e deve dar especial atenção à contação de histórias. Tal espaço contribui para a aprendizagem em todos os aspectos: cognitivo, físico, psicológico, moral ou social, sensorial e receptivo aponta 'Fuego'.

E os desdobramentos do trabalho do bibliotecário e contador de história no mundo póscovid-19? Nesse pleito fica a constatação que as bibliotecas escolares precisam interagir com seu público. Necessitam mudar! A esse respeito, diante a árdua confeitaria do momento, o ato de contar histórias deve impregnar, em todos os sentidos, a construção da identidade cultural de um indivíduo, executando uma dupla via de cidadania e educação. 
O bibliotecário em pauta na prática de contar histórias: uma atividade educativa incentivada nas bibliotecas escolares da Grande Vitória, Espírito Santo, Brasil

Assim, a ambiência da biblioteca escolar e o profissional da informação atuam de forma mediadora e criativa - isso estimula as crianças a imaginar e brincar. Essas interações que dão um grande passo para o enriquecimento e desenvolvimento da personalidade/humanização porquanto o fantasiar e o (re)criar antecedem a leitura. Portanto, resgatando os cinco protetores (Tierra, Fuego, Viento, Áqua e Corazón) sintetiza-se o rol de entrevista a seguinte locução: ‘o contar história, eis um fio de prumo a orientar o coração do mundo' nos rumos do sonho, da utopia e do pensar a humanidade.

A aposta que os fazem os (as) bibliotecárias protetores é que a preocupação com o outro. Nisso está o dever de intermediar qualidade a produtos e serviços de informação em pró da comunidade que atuam. Nessa via, os canais de contação de histórias no YouTube somam e maximizam subsídios em termos de benefícios socioeducacionais para se avançar, inovar e embasar novas práticas - empowerment - na dinâmica presencial e a distância, fortalecendo a cultura da paz. (\#somostodosbibliotecaescolar).

\section{Referências}

ALMEIDA, Maria da Gloria de Souza. A importância da literatura como elemento de construção do imaginário da criança com deficiência visual. Rio de Janeiro: Instituto Benjamin Constant, 2014.

ANDRADE, Lucas Veras de; MELO, Ana Caroline Viana de. Um diálogo entre a vida real e a literatura infanto-juvenil: uma experiência de leitura na perspectiva da produção de sentidos. Informação@Profissões, Londrina, n. 1, v. 6, p. 162-173, 2017. Disponível em: https://brapci.inf.br/index.php/res/v/67378. Acesso em: 01 ago. 2020.

ANTUNES, Ricardo. Os sentidos do trabalho: ensaio sobre a afirmação e negação do trabalho. São Paulo: Boitempo, 1999.

BARRETO, Rayara Bastos; SOUSA, Laiana Ferreira de. Protagonismo Midiático Infantil: análise do comportamento informacional de vlogueiros contadores de histórias. Informação em Pauta, Fortaleza, v. 2, p. 197-216, 2017. Disponível em:

https://brapci.inf.br/index.php/res/v/40868. Acesso em: 31 jul. 2020.

BORTOLIN, Sueli; BURGHI, Vera Jussara. A interação entre o bibliotecário e o leitor-ouvinte na contação de histórias. Informação@Profissões, Londrina, n. 1-2, v. 3, p. 213-226, 2014. Disponível em: https://brapci.inf.br/index.php/res/v/62476. Acesso em: 31 jul. 2020.

BOTTOMORE, Tom. Dicionário do pensamento marxista. Rio de Janeiro: Zahar, 1988.

BUSATTO, Cleomari. Narrando histórias no século XXI: tradição e ciberespaço. 2005. 132

f. Dissertação (Mestrado em Literatura) - Universidade Federal de Santa Catarina, 
Marcelo Calderari Miguel e Sandra Maria Souza de Carvalho

Florianópolis. 2005. Disponível em: http://www.tede.ufsc.br/teses/PLIT0195.pdf. Acesso em: 22 jun. 2020.

CAFÉ, Ângela Barcellos Coelho. Os contadores de histórias na contemporaneidade: da prática à teoria, em busca de princípios e fundamentos. 2015. 277 f.. Tese (Doutorado em Artes) - Universidade de Brasília, Brasília, 2015. Disponível em:

https://repositorio.unb.br/handle/10482/19310. Acesso em: 29 jul. 2020.

CARVALHO, Ana Cristina Guimarães; NASCIMENTO, Maria Gezilda e Silva; BEZERRA, Midinai Gomes. A mediação da informação na narrativa oral e na história de vida: proposições dialogais. Revista Digital de Biblioteconomia \& Ciência da Informação, Campinas, n. 2, v. 16, p. 461-482, 2018. Disponível em:

https://brapci.inf.br/index.php/res/v/39990. Acesso em: 10 ago. 2020.

COSTA, Patrícia Evellyn; RIBEIRO, Janete Santa Maria. A importância de contar história na educação infantil. Revista Eletrônica Científica Inovação e Tecnologia, Rebouças, v. 8, n. 22, p. 1-18, 2017. Disponível em: https://periodicos.utfpr.edu.br/recit/article/view/e4771/pdf_1. Acesso em: 27 maio 2020.

FLECK, Felícia de Oliveira; CUNHA, Miriam Figueiredo Vieira da; NAVARRA, Maite Comalat. A contação de histórias nas bibliotecas públicas de Barcelona: impressões de viagem. Informação \& Informação, Londrina, n. 3, v. 23, p. 696-707, 2018. Disponível em: https://brapci.inf.br/index.php/res/v/108408. Acesso em: 31 jul. 2020.

FREITAS, Rose de. Projeto de Lei do Senado no 94, de 2018. Altera a Lei n ${ }^{\circ} 12.244$, de 24 de maio de 2010, para estabelecer obrigação de construir biblioteca escolar em todas as novas escolas públicas de educação básica. Senado Federal: Atividade Legislativa: Comissão de Constituição, Justiça e Cidadania: Parte integrante do Avulso do PLS n94, 2018. Disponível em: https://legis.senado.leg.br/sdleg-getter/documento?dm=7643431\&disposition=inline. Acesso em: 13 maio 2020.

GARCEZ, Eliane Fioravante. As competências do bibliotecário na educação básica: reflexões de rede. Perspect. ciênc. inf., Belo Horizonte, v. 19, n. 4, p. 3-24, dez. 2014. Disponível em: https://www.scielo.br/pdf/pci/v19n4/a02v19n4.pdf. Acesso em: 14 jul. 2020.

GIORDANO, Alessandra. A arte de contar histórias e o conto de tradição oral em práticas educativas. Construção Psicopedagógica, São Paulo, v. 21, n. 22, p. 26-45, 2013. Disponível em: http://pepsic.bvsalud.org/pdf/cp/v21n22/04.pdf. Acesso em: 03 ago. 2020.

GRANATO, Leonardo; LOPES, Fernanda Tarabal; COSTA, Alessandra de Sá Mello da. Historia e Investigación Social Cualitativa: Reflexiones en Torno de la Historia Comparada y la Historia de Vida. Organizações \& Sociedade, Porto Alegre, v. 27, n. 94, p. 508-531, 2020. Disponível em: http://www.spell.org.br/documentos/ver/58727. Acesso em: 31 jul. 2020.

GREENHILL, Pauline. Reality, magic, and other lies: fairy-tale film truths. Detroit: Wayne State University Press: WSU Press, 2020. 268p.

KNOCHE, Liège Maria Martins. Contar, ler e brincar: a importância da contação e da leitura de histórias aliadas ao lúdico como agentes transformadores da rotina hospitalar. Revista 
O bibliotecário em pauta na prática de contar histórias: uma atividade educativa incentivada nas bibliotecas escolares da Grande Vitória, Espírito Santo, Brasil

ACB: Biblioteconomia em Santa Catarina, Florianópolis, n. 1, v. 18, p. 576-598, 2013. Disponível em: https://revista.acbsc.org.br/racb/article/view/871. Acesso em: 31 jul. 2020.

LOURENÇO, Adriana. Contando histórias e encantando nos espaços de leitura. Ciência da Informação em Revista, Maceió, n. 2, v. 1, p. 28-31, 2014. Disponível em: https://www.seer.ufal.br/index.php/cir/article/view/1442. Acesso em: 19 jul. 2020.

LUCIANO, Ana Margarida Vieira. O contador de histórias: das representações literárias ao contexto educativo atual. 2014. 196 f. Dissertação (Mestrado em Gestão da Informação e Bibliotecas Escolares) - Universidade Aberta: UAb Portugal, Lisboa, 2014. Disponível em: https://repositorioaberto.uab.pt/handle/10400.2/3429. Acesso em: 25 set. 2020.

MATEUS, Ana do Nascimento Biluca et al. A importância da contação de história como prática educativa na educação infantil. Pedagogia em Ação, Belo Horizonte, n. 1, v. 5, p. 5469, 2013. Disponível em:

http://periodicos.pucminas.br/index.php/pedagogiacao/article/view/8477. Acesso em: 11 ago. 2020.

MENEZES, Jaileila de Araújo et al. A contação de histórias no Instagram como tecnologia leve em tempos pesados de pandemia. Psicol. Soc., Belo Horizonte, v. 32, e020012, 2020. Disponível em: https://www.scielo.br/pdf/psoc/v32/1807-0310-psoc-32-e020012.pdf. Acesso em: 12 nov. 2020.

MIHIĆ, Sanja Skočić; MAICH, Kimberly; RAMIĆ, Nádia Novak. The role of bibliotherapy and therapeutic storytelling in creating inclusive classroom communities. In: PETERSEN, Amy $\mathrm{J}$ (ed.). Handbook of research on classroom diversity and inclusive. Hershey, PA, USA: IGI Global, 2017, p.375-398.

PIVETTA, Marcos. Diáspora há 2,5 milhões de anos. Pesquisa Fapesp: Fundação de Amparo à Pesquisa do Estado de São Paulo, São Paulo, Agência Fapesp: notícia arqueologia, ago. 2019. Disponível em: https://revistapesquisa.fapesp.br/diaspora-ha-25-milhoes-de-anos/. Acesso em: 10 ago. 2020.

ROBSON, José. A oralidade do narrador de histórias. Centro de Contação de Histórias, São Paulo, jun. 2020. Disponível em: https://contadoresdehistorias.com.br/blog/a-oralidadedo-narrador-de-historias/. Acesso em: 11 set. 2020.

RONCHI, William Hiroshi Abeno. O sonho, a utopia e o pensar: poesias. Revista Clóvis Moura de Humanidades, Teresina, n. 1, v. 6, p. 88, 2020. Disponível em: https://revistacm.uespi.br/revista/index.php/revistaccmuespi/article/view/337/155. Acesso em: 19 jul. 2020.

SEVERINO, Amanda Vilamoski; BEDIN, Sonali Paula Molin. O Bibliotecário como disseminador da informação nas escolas. In: BLATTMANN, Úrsula; VIANNA, William Barbosa (org.) Inovação em escolas com bibliotecas. Florianópolis: Dois Por Quatro, p.113$117,2016$.

SILVA, Aline Pacheco; BARROS, Carolyne Reis; NOGUEIRA, Maria Luísa Magalhães; BARROS, Vanessa Andrade. 'Conte-me sua história': reflexões sobre o método de História de 
Vida. Mosaico: Estudos em Psicologia, Belo Horizonte, v. 1, n. 1, 2007. Disponível em: https://periodicos.ufmg.br/index.php/mosaico/article/view/6224. Acesso em: 26 jul. 2020.

SILVA, Antônia Janiele Moreira da; ALENCAR, Aline Quesado; BERNARDINO, Maria Cleide Rodrigues. Biblioteca escolar e mediação da leitura: estudo sobre a importância da contação de história para a formação do leitor. Revista Folha de Rosto, Fortaleza, v. 3, p. 3644, 2017. Disponível em: https://brapci.inf.br/index.php/res/v/39231. Acesso em: 31 jul. 2020.

SILVA, Ivanice Prado da; SILVA, Winglyd Thais do Nascimento da; LOURENÇO, Adriana. Contação de História como Mediação de Leitura: contribuição na formação do Bibliotecário. Ciência da Informação em Revista, Maceió, n. 2, v. 3, p. 10-17, 2016. Disponível em: https://brapci.inf.br/index.php/res/v/36360. Acesso em: 31 jul. 2020.

SOUSA, Ana Lívia Mendes de; SÁ, Paloma Israely Barbosa de; BUFREM, Leilah Santiago. Memória e Oralidade: a cantoria de viola e a contação de histórias na Região do Cariri Cearense. Revista Ibero-Americana de Ciência da Informação, Brasília, v. 13, n. 2, p. 619635, 24 abr. 2020. Disponível em: https://brapci.inf.br/index.php/res/v/141280. Acesso em: 31 jul. 2020.

SOUSA, Laiana Ferreira de; LIMA, Izabel França de Lima; CAVALCANTE, Lídia Eugenia. 'Vestindo o personagem': o contador de histórias do século XXI. In: ENCONTRO NACIONAL DE PESQUISA EM CIÊNCIA DA INFORMAÇÃO: ENANCIB, 18. 2017, Marília. [Anais...]. Marília: ANCIB: Portal de Conferências, 2017. [21] f. Disponível em: http://enancib.marilia.unesp.br/index.php/XVIII_ENANCIB/ENANCIB/paper/view/572. Acesso em: 23 jul. 2020.

SOUZA, Ana Cleide Patrício de. Recursos auxiliares e criativos para contação de histórias na biblioteca escolar. Biblionline, João Pessoa, v. 13, p. 17-20, 2017. Disponível em: https://brapci.inf.br/index.php/res/v/16356. Acesso em: 31 jul. 2020.

VICENTE, Kalinde Braga Augusto. A formação do contador de histórias hoje: a parceria teatral e outros caminhos. 2015. 136 p. Dissertação (Mestrado) - Universidade Estadual de Campinas, Instituto de Artes, Campinas, 2015. Disponível em: http://www.repositorio.unicamp.br/handle/REPOSIP/285200. Acesso em: 26 ago. 2018.

VIGOTSKY, Lev Semyonovich. Imaginação e criação na infância: ensaio psicológico: livro para professores. São Paulo: Ática, 2009. 135 p. 